\title{
Launching the innovative BIM module for the architecture and built environment programme in China
}

\author{
L. Tang, R. Jin \& K. Fang \\ Department of Architecture and Built Environment, \\ University of Nottingham Ningbo China, China
}

\begin{abstract}
Building Information Modelling (BIM), the booming digital technology in the global architectural, engineering, and construction (AEC) industries, is changing the project management not only from the technological perspective but also the way of team collaboration. As academia staff in the AEC field, the authors have been working on exploring the implementation of BIM education in the university curriculum, equipping students with the initial BIM knowledge, and further training students to prepare themselves in the future AEC job market. The newly created BIM module in the university recruited final year students from multiple disciplines, including architecture, civil engineering, and architectural environmental engineering. A real-life project was used in the module to enable students from different backgrounds to work in a team by utilizing the BIM as the teamwork tool. Students' group work of applying BIM is presented in this study. Discussion from student group presentations sparked insights on how to overcome potential barriers when replacing the traditional 2D system with BIM. This study is developed to provide an example and initial thoughts of how the university education could be updated to meet the AEC industry need.

Keywords: BIM, AEC, education, collaboration, training, Revit, module.
\end{abstract}

\section{Introduction}

China, a continuously booming construction market, which accounted for $47.9 \%$ of the Asia-Pacific construction value in 2013 according to MarketLine [1], is demanding the adoption of BIM in the building industry. The recently published 
national BIM survey report by Shanghai Construction Trade Association (SCTA) \& Luban Consulting (LC) [2] indicated that though BIM implementation in China's construction industry was largely limited in clash detection and take-off estimate, both clients and contractors had high expectations of BIM input into their projects. Multiple recent investigations (e.g. Shenzhen Exploration \& Design Association (SZEDA) [3] and SCTA \& LC [2]) indicated that there were insufficient qualified BIM staffs in China's AEC project management. The gap between insufficient well-trained BIM personal and the growing demand for BIM usage remains to be filled in the coming years.

Adding BIM in the curriculum is not simply changing the engineering tool from 2D Computer Aided Design (CAD) to 3D visualization, but more significantly, the way of collaboration, communication, and coordination among project team members. This study aimed to explore the BIM education through university course, with the overall goal to provide students in AEC disciplines with not only BIM software skills, but also the collaboration experience through teamwork. Students' group projects were described throughout the multidisciplinary collaboration involving subjects in architecture, civil engineering, and architectural environmental engineering. Their feedback to this newly launched BIM module was summarized. Finally, suggestions for further enhancing the BIM education in China were provided.

\section{Background of BIM education}

Lack of BIM personnel was perceived by over $67 \%$ of Chinese industry practitioners as one major obstacle in widening the usage of BIM in AEC fields according to the newly released survey report from SCTA \& LC [2]. Similarly, lack of expertise within the project team and the organization was also ranked as top reason for not using BIM in the U.K. industry survey report from Eadie et al. [4]. In recent years, the BIM practice has been extended in multiple areas including but not limited to vertical BIM, horizontal BIM, heavy BIM, and "green" BIM, etc. (Rahman et al. [5]). The diversified BIM areas and new BIM movements have created a greater demand on competent BIM professionals and college graduates with relevant BIM knowledge (Jäväjä and Salin [6]). Educational institutions play a key role in the BIM transition (Jäväjä and Salin [6]). Insufficient resources and university conservations are key barriers to promoting engineering education to meet the demands (Trine [7]).

In the recent survey conducted during March of 2015 in Beijing, China to a London-based international engineering firm, researchers collected 42 responses from the firm's Mechanical, Electrical, and Plumbing (MEP) department. Among the survey responses, over half of them had never used BIM in their projects, and only $19 \%$ of these MEP engineers had learned BIM in college, and the rest survey participants adopted BIM for the first time in the work or internship. When asked how easy it was to learn a new BIM software tool, close to $75 \%$ of respondents claimed that it was "difficult" or "very difficult" to learn BIM tools. This could be due to the fact that most MEP engineers learned the traditional 2D Computer 
Aided Design (CAD) in school and was not aware of BIM. It is not uncommon that experienced engineers or designers have been used to working with 2D drawings and are reluctant to switch to BIM (Gong [8]). Considering the international background of this surveyed firm and their industry-leading technologies in China, it is fair to confer that there is still a large potential for enhancing BIM usage in the near future of China's AEC industries. The low percentage of survey participants stating that they had used BIM in college would indicate the importance of college BIM education to work as the pre-career training to future AEC personnel. College graduates equipped with BIM techniques could also reduce the industry investment in BIM training in the long run.

The engineering professions nowadays call for integrated ways of working, and collaboration is considered the key to successful project delivery (Jäväjä and Salin [6]). The market survey of Eadie et al. [4] to UK BIM users showed that "collaboration is key to successful BIM" was listed as the top impact of BIM. BIM education cannot be approached in the way adopted for CAD, as BIM is not simply a tool for generating drawings but also a comprehensive method for information management and analysis, as well as collaboration and teamwork (Sacks and Pikas [9]). Therefore, BIM education should not only impart software related knowledge to college students but also deliver the teamwork and collaboration experience. This is confirmed by Mathews [10] that the new collaborative learning environment simulated in BIM work could prepare and equip students with collaborative problem-solving skills. The construction industry needs graduate engineers equipped with knowledge and skills (Pikas et al. [11]). Russell et al. [12] concluded that personal BIM skillsets have a significant impact on a student's career opportunities. Currently, the BIM education and training for AEC subjects within universities in countries like China is still not widely implemented. Some of the existing studies of BIM education worldwide are summarized in Table 1.

Implementation level of BIM education in universities may vary from country to country and in different schools. Some universities (e.g. Jäväjä and Salin [6]) may have started the brainstorming of how to incorporate BIM in education and is still undergoing the exploration stage of further adopting BIM in certain subjects within the engineering programme. Other schools (e.g. Nawari [13], Kim [15] and Livingston [17]) has utilized BIM as an assistance tool in enhancing students learning in certain subjects such as cost estimate, $3 \mathrm{D}$ visualization to replace $2 \mathrm{D}$ drawings, and structural design. There are also institutions at an active explorative stage of adopting case studies to provide students with collaborative teamwork practice (e.g. Mathews [10] and Sharag-Eldin and Nawari [16]). The trend of BIM education, as suggested by Pikas et al. [11], should be implemented at the programme level rather than an isolated course or module It has been realized from both industry and academia that BIM in AEC education has become a necessity (Solnosky and Parfitt [14]). Its effects on the education have not been thoroughly studied although BIM has proven to provide positive opportunities to advanced education (Solnosky and Parfitt [14]). 


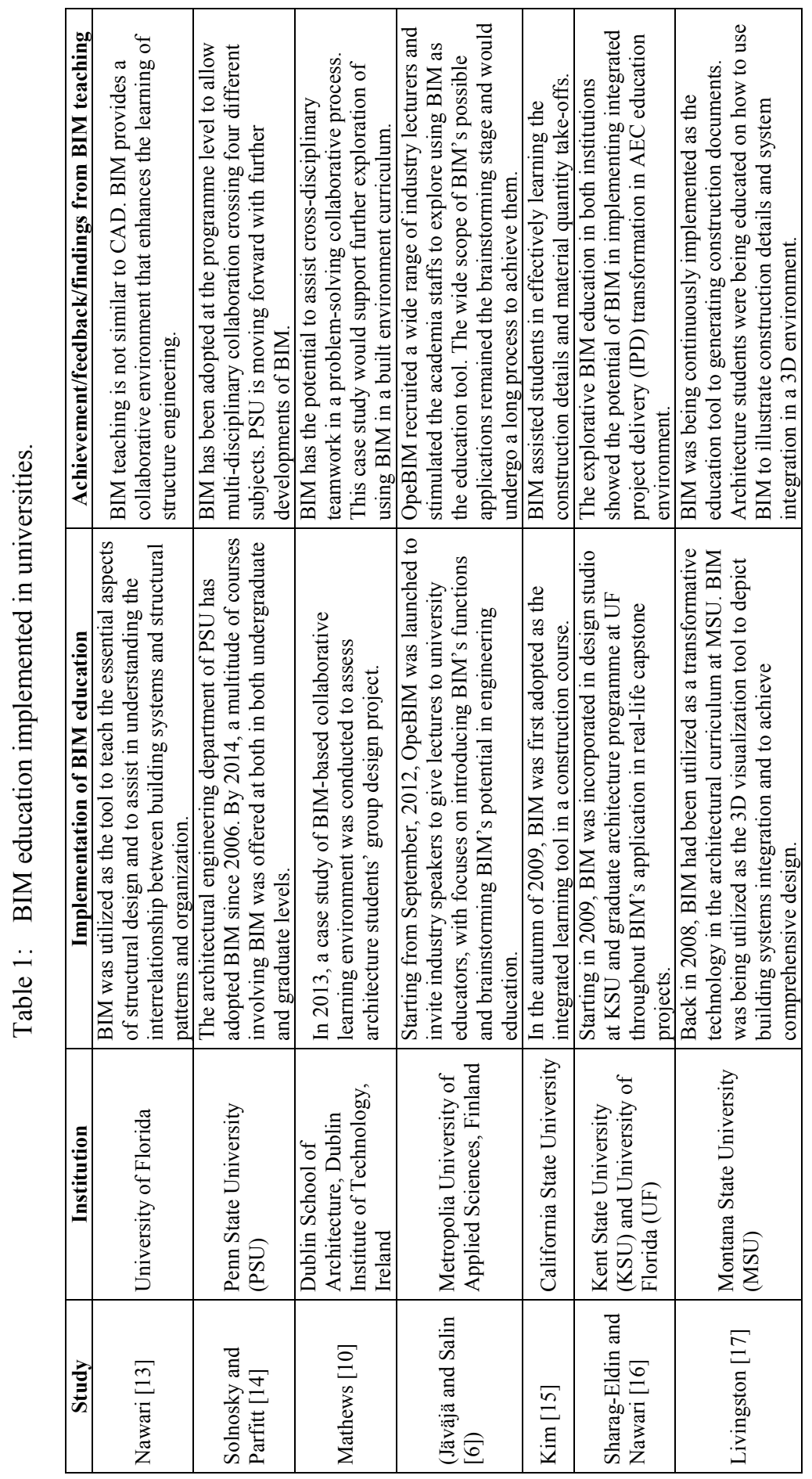




\section{BIM module at University of Nottingham Ningbo China (UNNC)}

Compared to the active implementation of BIM education in the US and Europe, China, the giant market of AEC industries, is facing the gap between the urgent industry needs of BIM professionals and lack of education resources in universities. University of Nottingham Ningbo China (UNNC), as the first international-based university built in China, has been providing British education modules to both domestic and international students since it was founded in 2004. The Department of Architecture and Built Environment (ABE) has been keeping investigating effective teaching in preparing students with state-of-the-art knowledge and technologies that would enhance students' competence in their future career in AEC industries. In the autumn of 2014, the ABE course at UNNC obtained the unconditional full validation from The Royal Institute of British Architects (RIBA) Education Committee. This was a key milestone for the course to be the first Internationally RIBA-validated China. The first BIM module at UNNC was also launched in the same semester to recruit students from multiple disciplines including architectural environmental engineering, architecture, and civil engineering to enable the cross-disciplinary collaboration. This module aimed to provide students with understanding of how BIM - as well as other related digital technologies - is rapidly contribute to change management practices on advanced construction projects.

The BIM module was open to multiple disciplines within the Faculty of Science and Engineering at UNNC. In total 30 students were enrolled in this module. The majority of them were in the final year's undergraduate study, with their own background in construction engineering, structural engineering, architectural design, or building services engineering. None of them had learned BIM beforehand. Like other peer schools in China, CAD was the instruction tool to generate engineering drawings in the UNNC course. The module was designed to achieve these learning outcomes (LO) in accordance with the Architects Registration Board (ARB [18]), the British authority that prescribes the qualifications and practical experience required for UK registered architects. Items within the General Criteria (GC) and Graduate Attributes (GA) are included in the benchmarking of qualifications in ARB. For example, GC2 was defined as "Adequate knowledge of the histories and theories of architecture and the related arts, technologies and human sciences". GC2 could be further divided into three subcategories, namely GC2.1 until GC2.3.

LOs of this BIM module are listed below:

1. Know the main types of BIM and other related digital technologies used for design, work-flow planning, co-ordination and communication on site (GC2.1);

2. Articulate the major benefits that are claimed for the use of BIM and that are driving their development moving from $2 \mathrm{D}$ to $3 \mathrm{D}$ and multidimensional design and construction environment (GC3.1; GA1.1); 
3. Demonstrate familiarity with current ideas about information overload and the value of information within organizations (GA1.5);

4. Appreciate the characteristics of organizational approaches to understanding use of these technologies (GC6.1; GC6.2; GA1.3; GA1.6);

5. Apply these approaches to assessing the positive and negative impact of these technologies on different stages of the real-life projects (GC8.1; GC8.2; GC8.3; GC9.3; GC10.2; GA1.1; GA1.2; GA1.3);

6. Understand how these technologies are changing the management and delivery of projects (GC11.3; GA1.3).

To achieve the LOs, the module consisted of lecture, BIM labs, and group presentation. Weekly lectures were delivered to students on multiple BIM extended topics presented by guest speakers from both academia and AEC industries. Guest speakers shared their BIM related experience with students, such as cost estimate, IFC standards, 5D BIM, challenges of BIM in real life, etc. A four-week training session was provided during the autumn semester of 2014 to students with skill-sets of Revit Architecture, Structure, and MEP. In total four BIM labs were provided for each student to go through the series of Revit-based building models. Students were required to build a "dream house" involving topography, architectural elements, structure, and MEP systems.

By the end of the four-week training period, group project was assigned to each five-member student team to adopt Revit as the BIM tool to provide the $3 \mathrm{D}$ files of architecture, structure, and MEP for a teaching building under construction in the UNNC campus. Each team consisted of students from different disciplines. Therefore, the roles of each team member were easily defined. The architecture student played the role as architect to create the 3D architectural model, the civil engineering students then generated the structural form in Revit Structure. The environmental engineering student used Revit MEP to add building services facilities based on the previous models created by other team members. The Revit system ensured that all team members worked in a close collaborative environment. The construction engineering student finally generated the take-off estimate using the quantities of elements generated in Revit. Figure 1 displayed an example of the group project delivery process from one student team.

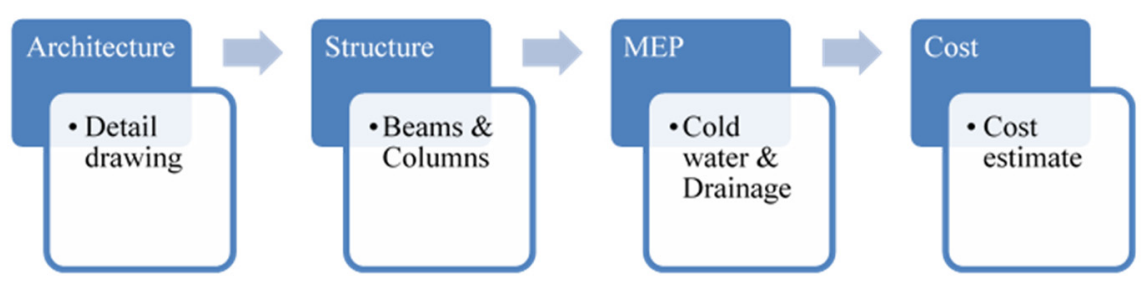

Figure 1: Group project process. 2.

Each part displayed in Figure 1 is further provided with an example in Figure 


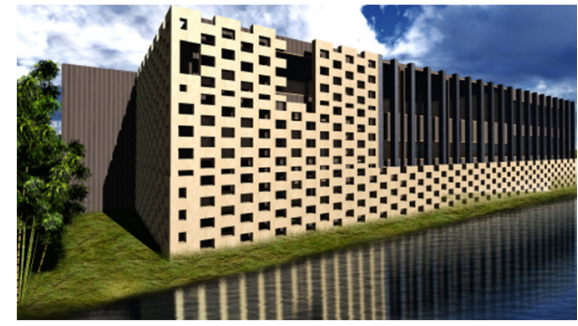

(a) Architectural form.

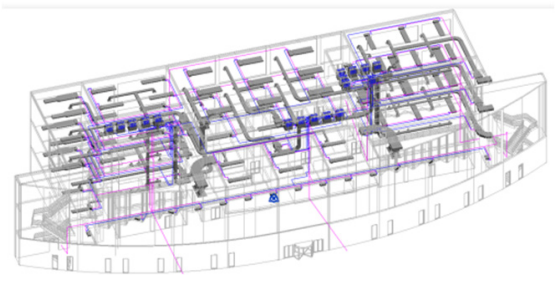

(c) MEP system.

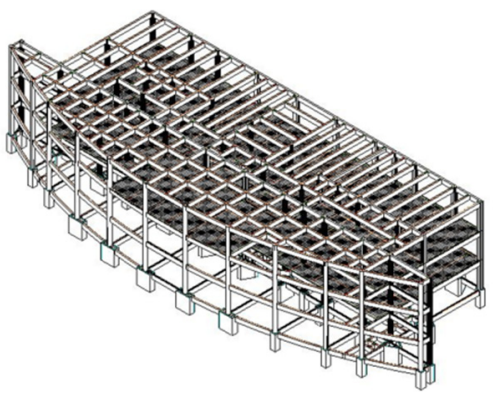

(b) Structural form.

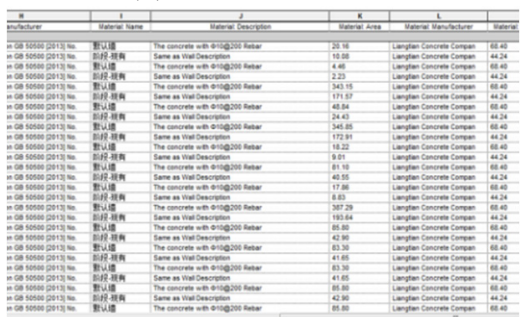

(d) Quantity take-off spreadsheet.

Figure 2: Group project of the real-life building project.

At the end of the group project each team presented their work with each member presenting the individual contribution to the teamwork. During the presentation, students shared their experience of how BIM impacted the project collaboration, the pros and cons of using BIM as compared to $2 \mathrm{D} \mathrm{CAD}$, and the project delivery process. The group presentation was peer assessed apart from the assessment of three academia staffs at UNNC. Students gained their initial experience of adopting BIM to replace the existing 2D CAD drawings. The advantages of BIM over CAD from the six teams are summarized below:

- Reduction in the confusions of construction details which could occur in CAD;

- Saving time in take-off estimates and assistance in checking the cost list;

- Better visual representation of project and construction elements;

- Easier exploration of different design options and concepts with the owner's budget.

The disadvantages of BIM were also presented and summarized as below:

- $\quad$ Not user-friendly in generating certain elements (e.g. stairs and railings);

- $\quad$ Requiring all project members to have the skill-sets of the same BIM tool; It could be extended from this statement of potential barriers in the real world if not all project team members are using the same BIM tool, or some of them do not have the BIM skill. Assuming that if some engineering staffs are still using $2 \mathrm{D}$ representation, while other peers may have adopted 3D BIM, the "translation" between 2D and 3D would be time-consuming; 
- Some small errors detected when using Revit such as façade walls;

- Cost errors.

Table 2 and Table 3 described how this BIM module provided students with qualifications according to items in GC and GA.

Table 2: General criteria mapping based on existing module learning outcomes.

\begin{tabular}{|c|c|c|}
\hline $\begin{array}{l}\text { ARB } \\
\text { general } \\
\text { criteria }\end{array}$ & $\begin{array}{l}\text { I, P } \\
\text { or } \\
\text { A }\end{array}$ & $\begin{array}{l}\text { Brief description of how the ARB general criteria are } \\
\text { achieved/evidenced }\end{array}$ \\
\hline GC2.1 & I & $\begin{array}{l}\text { BIM was introduced and discussed during the lectures as compared } \\
\text { to CAD. Specifically, students were exposed to the main types of } \\
\text { BIM and other digital technologies used in the building design and } \\
\text { management on jobsites. Students were provided with the picture } \\
\text { of how the BIM is developed and applied under the traditional } \\
\text { design and construction culture and social background (LO1). }\end{array}$ \\
\hline GC3.1 & A & $\begin{array}{l}\text { The lecture of sculpture followed by hands-on work in a 3D model } \\
\text { trained students with the skill-sets of 3D technology. Through the } \\
\text { BIM essay writing and group practice, students were reinforced } \\
\text { with the understanding and experience of the benefits of using } \\
\text { BIM (LO2). }\end{array}$ \\
\hline GC6.1 & A & $\begin{array}{l}\text { The lecture of Integrated Project Delivery (IPD) System } \\
\text { introduced students how the roles of architects were moving } \\
\text { towards more collaboration with other project team parties. In the } \\
\text { teamwork environment of the group project, students practiced } \\
\text { using BIM to improve the coordination, collaboration, and } \\
\text { communication among group members. Group presentation } \\
\text { delivered the understanding of the duties and professionalism of } \\
\text { architects (LO4). }\end{array}$ \\
\hline GC6.2 & A & $\begin{array}{l}\text { Through both the IPD lecture and BIM group project, students } \\
\text { gained both theoretical knowledge and practical experience on the } \\
\text { role of architects within the project team. Students were asked in } \\
\text { their final group presentation specifically of how the trends of } \\
\text { using IPD and BIM impacted the roles of architects (LO4). }\end{array}$ \\
\hline GC8.1 & A & $\begin{array}{l}\text { The group project in this BIM module used a real-life project in } \\
\text { the UNNC campus. Students were trained with the skills of } \\
\text { investigation, critical appraisal, and decision on architectural form, } \\
\text { structures, and materials with the assistance with BIM technology } \\
\text { (LO5). }\end{array}$ \\
\hline GC8.2 & A & $\begin{array}{l}\text { Students applied their knowledge from previous modules into the } \\
\text { comprehensive group project by using BIM as the approach. They } \\
\text { assessed BIM's impact on different stages of the project, including } \\
\text { architectural, structural, and MEP design (LO5). }\end{array}$ \\
\hline GC8.3 & A & $\begin{array}{l}\text { The lecture of commonly applied building materials (i.e. concrete, } \\
\text { wood, and steel) was introduced in the lecture. BIM was adopted } \\
\text { to visualize the material and systems. Students explored and } \\
\text { mastered the skills of building the system on the selected materials } \\
\text { in BIM (LO5). }\end{array}$ \\
\hline
\end{tabular}


Table 2: Continued.

\begin{tabular}{|l|l|l|}
\hline $\begin{array}{l}\text { ARB } \\
\text { general } \\
\text { criteria }\end{array}$ & $\begin{array}{l}\text { I, P } \\
\text { or } \\
\text { A }\end{array}$ & $\begin{array}{l}\text { Brief description of how the ARB general criteria are } \\
\text { achieved/evidenced }\end{array}$ \\
\hline GC9.3 & A & $\begin{array}{l}\text { The building service (MEP) design was integrated to the group } \\
\text { project. Students added the MEP system after the architectural and } \\
\text { structural design stages. BIM was used as the tool to detect potential } \\
\text { spatial clashes, which may not be found in traditional 2D design } \\
\text { (LO5). }\end{array}$ \\
\hline GC10.2 & A & $\begin{array}{l}\text { Cost estimate was part of the module and group project. Students } \\
\text { performed the cost estimate during the group project in the BIM- } \\
\text { driven system and truly understood the impact of BIM in cost } \\
\text { estimate by utilizing the quantity information generated from the } \\
\text { BIM system (LO5). }\end{array}$ \\
\hline GC11.3 & A & $\begin{array}{l}\text { Students were introduced in the lecture in light of the IPD compared } \\
\text { to the traditional business model and in the building industry. By } \\
\text { recruiting BIM as the tool in the project delivery process, students } \\
\text { gained the experience of how BIM, as the emerging trend, was } \\
\text { changing the way that the design and construction is managed and } \\
\text { delivered (LO6). }\end{array}$ \\
\hline
\end{tabular}

Note: I: introduction, P: practice, A: assessment.

\section{Findings and discussion}

The BIM module at UNNC provided students with initiatives to design their own sample projects through lab activities. Later the group project was assigned to enable the inter-disciplinary collaboration. Students were trained with real-world problem solving skills and critical thinking apart from the teamwork skill-sets in BIM environment. Student presentations also sparked some thinking of adopting $\mathrm{BIM}$ in the local AEC industries. For example, would it be much more efficient in project delivery if all parties agreed on the same BIM tool? Some other issues have also been thought of in the future BIM education at UNNC, for instance, whether BIM should be introduced in the earlier years of undergraduate course or pending until students have gained the knowledge in their own disciplines.

This BIM module worked as a guide to inspire students' future career in the AEC industries, especially for those who have interests in pursuing BIM related career. It is suggested that students' BIM learning should not end with the module, but continue in their future work. Some students adopted BIM in their final year research project during the same semester. It is indicated that BIM education would expand students' horizon in both job search or academia research.

The BIM education implementation could vary in different institutions, but generally, each institution may develop the BIM education programme from brainstorming by inviting industry speakers, starting BIM in a single coursework, subject or module, motivating cross-disciplinary collaboration, moving forward to multiple modules at the programme level, and further expanding to BIM training to industry professionals. The BIM education at UNNC is currently under further 
Table 3: Graduate attributes mapping based on existing module learning outcomes.

\begin{tabular}{|l|l|l|}
\hline $\begin{array}{l}\text { ARB } \\
\text { graduate } \\
\text { attributes }\end{array}$ & $\begin{array}{l}\text { I, P } \\
\text { or } \\
\text { A }\end{array}$ & $\begin{array}{l}\text { Brief description of how the RIBA graduate attributes are } \\
\text { achieved/evidenced }\end{array}$ \\
\hline GA1.1 & A & $\begin{array}{l}\text { Using BIM in the design stage could achieve various benefits } \\
\text { such as automatic low-level corrections when changes are } \\
\text { required, and earlier collaboration of multiple design disciplines. } \\
\text { Students applied the professional practice and academic } \\
\text { discipline in architecture by utilizing BIM in generating the } \\
\text { design proposals. They learned how the BIM impact the design } \\
\text { stage by incorporating BIM into their previously learned body of } \\
\text { knowledge (LO2, LO5). }\end{array}$ \\
\hline GA1.2 & A & $\begin{array}{l}\text { Students were encouraged to apply various communication } \\
\text { methods and techniques to present their final project. Revit was } \\
\text { the tool adopted for visualization and communication (LO5). }\end{array}$ \\
\hline GA1.5 & $\begin{array}{l}\text { Guest speakers from both academia and AEC industries were } \\
\text { invited to provide students with the picture of teamwork in a } \\
\text { project team from planning, design, construction, and post- } \\
\text { construction. Students gained the knowledge of the context of } \\
\text { the architect, who was in close collaboration with the } \\
\text { construction industry (LO3). }\end{array}$ \\
\hline GA1.6 & $\begin{array}{l}\text { This BIM module was designed to provide the cutting-edge } \\
\text { technological education to students who were entering the job } \\
\text { market. Through the lectures, real-life project teamwork and } \\
\text { assessment, students gained the understanding of how BIM had } \\
\text { been changing the traditional project delivery process and inter- } \\
\text { organizational collaboration. Upon the completion of this } \\
\text { module, students was equipped with the emerging BIM } \\
\text { technology and further identify their learning needs for } \\
\text { professional development in the future design and construction } \\
\text { industry (LO4). }\end{array}$ \\
\hline
\end{tabular}

Note: I: introduction, P: practice, A: assessment.

development. The experience of BIM education at UNNC could be shared with other peer schools in China and to deliver BIM to a wider coverage of AEC graduates and industry personnel.

\section{Conclusion}

The first BIM module launched at UNNC serves as the milestone in the BIM education in Chinese institutions. The evaluation of the module and student feedback motivated the researchers to further update BIM in the future education. Compared to developed countries such as US, BIM education is still limited and more training resources are in urgent need to meet the rising AEC market demands. The educators in this BIM module at UNNC believe that BIM should not be taught like 2D CAD, which had a high emphasis in software skill teaching, but instead encouraging the collaboration of student from different disciplines. 
Students should be motivated to apply BIM in an active way by seeking solutions for problems encountered in teamwork.

\section{Recommendations for future research}

The goal of BIM education at UNNC would be to expand it from a single module to the whole programme, and to provide training to local professionals considering the booming local BIM market. Continuous BIM education will be conducted in the coming school year. The BIM education will be updated according to student feedback. Future BIM education at UNNC will target on other modules and extend to post-graduate programmes.

\section{References}

[1] MarketLine Industry Profile, Construction in China, Reference Code: 00992801, p. 10, July 2014.

[2] Shanghai Construction Trade Association (SCTA) \& Luban Consulting, The annual 2014 investigation report of the current BIM application in construction firms, http://www.lubanway.com/index.php?controller= guandian\&action=guandian_front\&type $=3 \&$ guandian_id $=439$

[3] Shenzhen Exploration \& Design Association (SZEDA), Guide for BIM application and development in the engineering \& design industry of Shenzhen, Tianjin Science \& Technology Press, Tianjin, pp. 20-22, 2013.

[4] Eadie, R., Browne, M., Odeyinka, H., McKeown, C. \& McNiff, S., BIM implementation throughout the UK construction project lifecycle: an analysis. Automation in Construction, 36(2013), pp. 145-151, 2013.

[5] Rahman, Md. A., Suwal, S., and Jäväjä, P. Diverse approach of BIM in AEC industry: a study of current knowledge and practice, Proceedings of the CIB W78 2013: 30th International Conference - Beijing, China, 9-12 October, 2013.

[6] Jäväjä, S.S.P. \& Salin, J., BIM Education: Implementing and Reviewing "OpeBIM" - BIM for Teachers. Computing in Civil and Building Engineering, CASCE 2014, pp. 2151-2158, 2014.

[7] Trine, R. Engineering education: quality and competitiveness from the European perspective, TREE-disclosing conference - a report, TREE teaching and research in engineering in Europe, 2008.

[8] Gong, Y. Analysis of BIM application and challenges in China, China Market, 1005-6432 (2013) 46-0104-02, pp. 104-105, 2013.

[9] Sacks, R. \& Pikas, E., Building information modeling education for construction engineering and management. I: industry requirements, state of the art, and gap analysis, Journal of Construction Engineering and Management, 139(11), 2013.

[10] Mathews, M., BIM collaboration in student architectural technologist learning, AEI 2013 C ASCE 2013, pp. 1-13, 2013.

[11] Pikas, E., Sacks, R. \& Hazzan, O., Building information modeling education for construction engineering and management. II: procedures and 
implementation case study, Journal of Construction Engineering and Management, 139(11), 2013.

[12] Russell, D., Cho, Y.K. \& Cylwik, E., Learning opportunities and career implications of experience with BIM/VDC, Practice Periodical on Structural Design and Construction, 19(1), pp. 111-121, 2014.

[13] Nawari, N.O., The role of BIM in teaching structural design, Structures Congress 2015, pp. 2622-2631, 2015.

[14] Solnosky, R.L. \& Parfitt, M.K., A curriculum approach to deploying BIM in Architectural Engineering, AEI 2015, pp. 651-662, 2015.

[15] Kim, J., Use of BIM for effective visualization teaching approach in construction education, Journal of Professional Issues in Engineering Education and Practice, 138(3), pp. 214-223, 2011.

[16] Sharag-Eldin, A. \& Nawari, N.O., BIM in AEC education, Structures Congress, pp. 1676-1688, 2010.

[17] Livingston, C. From CAD to BIM: constructing opportunities in architectural education, AEI 2008: Building Integration Solutions, pp. 1-9, 2008.

[18] Architectures Registration Board, Prescription of qualifications: ARB Criteria at Parts 1, 2 and 3, London, pp. 2-9. 2010. 